\title{
Model Pemasaran Penguatan Kelompok Tani Tumpangsari Cabai-Tembakau di Provinsi Bali
}

\author{
Marketing Model for Strengthening the Tumpangsari Farmer Group \\ Chili-Tobacco in Bali Province
}

\author{
I Nengah Surata Adnyana \\ Fakultas Pertanian, Universitas Dwijendra, Bali, Indonesia \\ Email : surataadnyana@gmail.com
}

\begin{abstract}
Chili and tobacco are superior commodities from the government. These chili and tobacco commodities often cause inflation for the nation's economy, so they need to be managed properly. The development of these two commodities in the province of Bali is often cultivated in an intercropping manner, which has the potential for maximum production. The study was conducted in the province of Bali and was selected purposively. The population is 1,482 people. The research sample was 315 respondents. The sampling technique used is proportional random sampling. Furthermore, the data were analyzed qualitatively and quantitatively, and analyzed using descriptive statistical methods. All indicators of the research variables use an ordinal scale of 1 to 5. Determination of variable categories is based on scores, using the class interval formula. The purpose of this study (1) is to analyze the marketing subsystem of chilitobacco intercropping farmer groups on the strengthening of chili-tobacco intercropping farmer groups in Bali Province, (2) to create an appropriate marketing model for strengthening chili-tobacco intercropping farmer groups in Bali Province. The results showed that (1) the product marketing subsystem The product marketing subsystem which includes the sales area, place of sale, price determination, and market information is included in the low category, (2) the marketing model for strengthening chili-tobacco farmer groups can be done by forming cooperatives/ Association of Farmers Group (Gapoktan) professionally, by selling commodities that are still intact as well as commodities of chili and tobacco that have undergone processing. Suggestions that can be given: (1) sales area, where the sale should be expanded to a wider scope, (2) price determination of chili-tobacco commodity should be based on farming analysis conducted by farmers, (3) market information for farmers is improved again, (4) the establishment of cooperative institutions or Farmers' Group Associations (Gapoktan) that have already been formed are immediately utilized to handle the marketing of chili-tobacco products.
\end{abstract}

Keywords: Marketing, intercropping, chili-tobacco 


\begin{abstract}
ABSTRAK
Komoditi cabai dan tembakau merupakan komoditi unggulan daripada pemerintah. Komoditi cabai dan tembakau ini sering menyebabkan inflasi bagi perekonomian bangsa, sehingga perlu diusahatanikan secara baik. Perkembangan kedua komoditas ini di provinsi Bali sering diusahatanikan secara tumpangsari, yang sangat berpotensi untuk berproduksi secara maksimal. Penelitian dilakukan di Provinsi Bali dipilih secara purposive. Populasi berjumlah 1.482 orang. Sampel penelitian sebanyak 315 responden. Teknik pengambilan sampel yang digunakan secara proportional random sampling. Selanjutnya data tersebut dianalisis secara kualitatif dan kuantitatif, dan dianalisis dengan menggunakan metode statistik deskriptif. Semua indikator dari variabel penelitian tersebut menggunakan skala ordinal 1 sampai 5. Penentuan kategori variabel berdasarkan skor, dengan menggunakan rumus interval class. Tujuan penelitian ini (1) menganalisis subsistem pemasaran usahatani tumpangsari cabai-tembakau terhadap penguatan kelompok tani tumpangsari cabai-tembakau di Provinsi Bali, (2) membuat model pemasaran yang sesuai untuk penguatan kelompok tani tumpangsari cabaitembakau Provinsi Bali. Hasil penelitian menunjukkan bahwa (1) subsistem pemasaran hasil Subsistem pemasaran hasil yang meliputi wilayah penjualan, tempat penjualan, penentuan harga, dan informasi pasar termasuk kedalam kategori rendah, (2) Model pemasaran untuk penguatan kelompok tani cabai-tembakau dapat dilakukan dengan pembentukan koperasi/Gabungan Kelompok Tani (Gapoktan) secara profesional, dengan menjual komoditi yang masih utuh maupun komoditi cabai dan tembakau yang sudah mengalami pengolahan hasil. Saran yang dapat diberikan : (1) wilayah penjualan, tempat penjualan hendaknya diperluas kembali ke sekup yang lebih luas, (2) penentuan harga komoditi cabai-tembakau hendaknya berdasarkan analisa usahatani yang dilakukan oleh petani, (3) Informasi pasar bagi petani ditingkatkan kembali, (4) pembentukan lembaga koperasi atau Gabungan kelompok Tani (Gapoktan) yang sudah terbentuk segera dimanfaatkan untuk menangani pemasaran hasil cabai-tembakau.
\end{abstract}

Kata kunci : Pemasaran, tumpangsari, cabai-tembakau

\title{
PENDAHULUAN
}

\section{Latar Belakang}

Cabai dan tembakau merupakan komoditi unggulan dari kementerian pertanian sehingga perlu dikembangkan keberadaannya. Hal ini disebabkan karena dua komoditi ini sering menyebabkan infasi yang akan berpengaruh terhadap perekonomian suatu bangsa. Provinsi Bali usahatani tumpangsari cabai-tembakau memiliki prospek yang sangat baik untuk dikembangkan, hal ini didukung oleh kesuburan tanah yang baik, pengaturan air yang baik juga dapat mengembangkan potensi lokal suatu daerah sesuai dengan prinsip agribisnis.

Selama ini petani tumpangsari cabai-tembakau memiliki potensi kelembagaan berupa kelompok tani, berproduksi sepanjang tahun, mendapat perhatian yang baik dari Pemerintah. Disamping potensi juga mempunyai kelemahan dan kekurangan dalam pelaksaannya dilapangan mulai dari produksi yang masih berpluktuasi, pendapatan yang 
masih rendah, serta sub sistem pemasarannya yang masih tergolong kategori yang masih rendah (Adnyana, et al., 2020).

\section{Tujuan}

Penelitian ini memiliki tujuan untuk (1) menganalisis subsistem pemasaran usahatani tumpangsari cabai-tembakau terhadap penguatan kelompok tani tumpangsari cabaitembakau di Provinsi Bali, (2) membuat model pemasaran yang sesuai untuk penguatan kelompok tani tumpangsari cabai-tembakau Provinsi Bali.

\section{METODE PENELITIAN}

Penelitian ini dilaksanakan di lokasi usahatani tumpangsari cabai-tembakau yang ada di Provinsi Bali, dimulai pada bulan juli 2020 sampai dengan pebruari 2021. Terdiri dari dua kabupaten dan tiga kecamatan.

Kabupaten Gianyar meliputi (1) Kecamatan Sukawati terdiri dari 13 kelompok tani yang ada di Desa Sukawati, 4 kelompok tani yang ada di Desa Batubulan Kangin, dan 1 kelompok tani yang ada di Desa Celuk; (2) Kecamatan Payangan meliputi : 2 kelompok tani yang ada di Desa Kerta, dan 1 kelompok tani yang ada di Buahan Kaja. Kabupaten Bangli meliputi 1 kelompok tani yang ada di Desa Langgahan Kecamatan Kintamani. Jumlah Kelompok tani dari penelitian ini sebanyak 24, dengan jumlah populasi sebanyak 1.482 orang, dengan jumlah sampel sebnyak 315 orang yang diambil secara teknik proportional random sampling menggunakan formulasi teori slovin.

Pengumpulan data dilakukan dengan wawancara terstruktur menggunakan kuesioner, wawancara mendalam dan observasi. Selanjutnya data tersebut dianalisis secara kualitatif dan kuantitatif, dan dianalisis dengan menggunakan metode statistik deskriptif. Semua indikator dari variabel penelitian tersebut menggunakan skala ordinal 1 sampai 5. Penentuan kategori variabel berdasarkan skor, dengan menggunakan rumus interval class.

\section{HASIL DAN PEMBAHASAN}

Subsistem pemasaran mencakup pemasaran hasil-hasil usahatani pada tanaman cabaitembakau. Pemasaran sangat penting dalam pertanian karena kegiatan utamanya adalah untuk pengembangan informasi pasar. Subsistem pemasaran juga merupakan kegiatan usaha yang ditujukan untuk kegiatan merencanakan, menentukan harga, mempromosikan dan mendistribusikan komoditi hasil pertanian yang dapat menawarkan kebutuhan kepada pembeli seperti komoditi cabai-tembakau (Soekartawi, 1988).

Secara keseluruhan pemasaran cabai memperoleh rata-rata nilai pencapaian skor 1,93 $(38,73 \%)$ yang termasuk kategori rendah. Hal ini disebabkan pemasaran cabai dilihat dari parameter wilayah penjualan kebanyakan masih dalam skup desa sendiri, tempat penjualannya masih kebanyakan lewat pengepul di desa setempat, penentuan harga cabai kebanyakan ditentukan oleh pengepul, serta informasi pasar mengenai harga cabai diperoleh pada saat panen saja. 
Pemasaran tembakau mendapatkan rata-rata nilai $1,68(33,74 \%)$ termasuk kategori sangat rendah. Penyebabnya wilayah penjualan masih kebanyakan didalam desa sendiri, tempat penjualannya dipengepul, harga tembakau ditentukan oleh pengepul dan informasi pasar diperoleh pada saat panen dilakukan. Hal ini sesuai dengan penelitian Istanto et al., (2016) bahwa sistem pemasaran komoditi cabai dan tembakau masih menggunakan sistem pemasaran secara konvensional, dimana sistem konvensional ini merupkan sistem pemasaran yang memberi keleluasaan bagi para pelaku pemasaran untuk menjalankan bisnisnya. Capaian Hasil Subsistem Pemasaran Hasil CabaiTembakau secara keseluruhan disajikan pada Tabel 1.

Tabel 1. Capaian Hasil Subsistem Pemasaran Hasil

\begin{tabular}{|c|c|c|c|c|c|}
\hline \multirow{2}{*}{ No } & \multirow{2}{*}{ Variabel dan indikator } & \multirow{2}{*}{$\begin{array}{c}\text { Jumlah } \\
\text { skor }\end{array}$} & \multicolumn{2}{|c|}{$\begin{array}{c}\text { Pencapaian } \\
\text { skor }\end{array}$} & \multirow[t]{2}{*}{ Kategori } \\
\hline & & & (Angka) & $(\%)$ & \\
\hline \multirow[t]{6}{*}{1} & Pemasaran cabai & & & & \\
\hline & a. Wilayah penjualan & 576 & 1,82 & 36,57 & Rendah \\
\hline & b. Tempat penjualan & 818 & 2,59 & 51,93 & Rendah \\
\hline & c. Peenentuan harga & 450 & 1,42 & 28,57 & Sangat rendah \\
\hline & d. Informasi pasar & 596 & 1,89 & 37,84 & Rendah \\
\hline & Rata - rata (1) & 610 & 1,93 & 38,73 & Rendah \\
\hline \multirow[t]{8}{*}{2} & Pemasaran tembakau & & & & \\
\hline & a. Wilayah penjualan & 582 & 1,84 & 36,95 & Rendah \\
\hline & b. Tempat penjualan & 578 & 1,83 & 36,69 & Rendah \\
\hline & c. Penentuan harga & 436 & 1,38 & 27,68 & Sangat rendah \\
\hline & d. Informasi pasar & 530 & 1,68 & 33,65 & Sangat rendah \\
\hline & Rata-rata (2) & 531,5 & 1,68 & 33,74 & Sangat rendah \\
\hline & Total $1+2$ & $\begin{array}{l}1.141, \\
5\end{array}$ & 3,62 & 72,47 & \\
\hline & Rata-rata subsistem $\mathrm{pe}$ & an hasil & 1,81 & 36,23 & Rendah \\
\hline
\end{tabular}

Aspek penguatan kelompok tani terdiri dari hasil pelaksanaan pertemuan, kesepakatan aturan, sumber pelayanan informasi dan teknologi, penumbuhan jejaring kerjasama, dan produksi komoditi cabai dan tembakau. Materi pelaksanaan pertemuan yang dilakukan petani mendapatkan nilai pencapaian skor 3,42 (68,44\%) termasuk kategori tinggi. Materi pertemuan sering membahas masalah sarana produksi pertanian, teknik budidaya serta keadaan saluran irigasi, jarang membahas masalah teknik pemasarannya. Waktu pelaksanaan pertemuan mendapatkan nilai 3,01 (60,38\%) dengan kategori sedang, dengan waktu pertemuan yang dilakukan oleh kelompok tani rata-rata dilakukan satu bulan sekali. Capaian Hasil Pelaksanaan Pertemuan disajikan pada Tabel 2 . 
Tabel 2. Capaian Hasil Pelaksanaan Pertemuan

\begin{tabular}{|c|c|c|c|c|c|}
\hline \multirow[t]{2}{*}{ No } & \multirow[t]{2}{*}{ Pelaksanaan pertemuan } & \multirow{2}{*}{$\begin{array}{l}\text { Jumlah } \\
\text { skor }\end{array}$} & \multicolumn{2}{|c|}{$\begin{array}{l}\text { Pencapaian } \\
\text { skor }\end{array}$} & \multirow[t]{2}{*}{ Kategori } \\
\hline & & & (Angka) & $(\%)$ & \\
\hline 1 & $\begin{array}{l}\text { Waktu pelaksanaan } \\
\text { pertemuan }\end{array}$ & 951 & 3,01 & 60,38 & Sedang \\
\hline \multirow[t]{2}{*}{2} & Materi pertemuan & 1.078 & 3,42 & 68,44 & Tinggi \\
\hline & Rata-rata & $\begin{array}{c}1.014,5 \\
0\end{array}$ & 3,22 & 64,41 & Sedang \\
\hline
\end{tabular}

Capaian hasil kesepakatan aturan dan norma, penerapan sangsi aturan yang telah disepakati memperoleh nilai pencapaian skor tertinggi yaitu 3,83 (76,76\%) dengan kategori tinggi, hal ini disebabkan kelompok tani menjungjung tinggi penerapan sangsi dengan tegas sesuai dengan aturan yang telah disepakati. Nilai terendah pada aturan tertulis yang dimiliki kelompok tani 3,07 (61,46\%). Secara keseluruhan capaian hasil kesepakatan aturan memperoleh nilai rata-rata pencapaian skor 3,32 (66,58\%) yang tergolong kategori sedang. Capaian hasil kesepakatan Aturan dan Norma dapat disajikan pada Tabel 3 .

Tabel 3. Capaian Hasil Kesepakatan Aturan dan Norma

\begin{tabular}{|c|c|c|c|c|c|}
\hline \multirow[t]{2}{*}{ No } & \multirow[t]{2}{*}{ Kesepakatan aturan } & \multirow{2}{*}{$\begin{array}{l}\text { Jumlah } \\
\text { skor }\end{array}$} & \multicolumn{2}{|c|}{$\begin{array}{c}\text { Pencapaian } \\
\text { skor }\end{array}$} & \multirow[t]{2}{*}{ Kategori } \\
\hline & & & (Angka) & $(\%)$ & \\
\hline 1 & $\begin{array}{l}\text { Memiliki aturan } \\
\text { tertulis }\end{array}$ & 968 & 3,07 & 61,46 & Sedang \\
\hline 2 & $\begin{array}{l}\text { Memiliki aturan } \\
\text { lisan }\end{array}$ & 969 & 3,07 & 61,52 & Sedang \\
\hline \multirow[t]{2}{*}{3} & Penerapan sangsi & 1.209 & 3,83 & 76,76 & Tinggi \\
\hline & Rata-rata & $\begin{array}{c}1.048,6 \\
7 \\
\end{array}$ & 3,32 & 66,58 & Sedang \\
\hline
\end{tabular}

Indikator sumber informasi dan teknologi yang diperoleh petani termasuk kategori yang tinggi dengan nilai pencapaian skor 4,09 (81,90\%). Kemampuan mengakses informasi pada media sosial mendapatkan nilai 2,58 (51,68\%) tergolong rendah. Secara keseluruhan capaian hasil sumber pelayanan informasi dan teknologi memperoleh nilai rata-rata 3,33 (66,79\%) kategori sedang. Sumber informasi dan teknologi petani bersumber dari penyuluh pertanian, antar kelompok tani lainnya, jarang mendapatkan sumber informasi dari pelaku usaha dan pelaku pemasaran..Capaian Hasil Sumber Pelayanan Informasi dan Teknologi disajikan pada Tabel 4.

Tabel 4. Capaian Hasil Sumber Pelayanan Informasi dan Teknologi

\begin{tabular}{llrrrr}
\hline \multirow{2}{*}{ No } & \multirow{2}{*}{$\begin{array}{l}\text { Pelayanan informasi } \\
\text { dan teknologi }\end{array}$} & \multirow{2}{*}{$\begin{array}{c}\text { Jumlah } \\
\text { skor }\end{array}$} & \multicolumn{2}{c}{$\begin{array}{c}\text { Pencapaian } \\
\text { skor }\end{array}$} & \multirow{2}{*}{ Kategori } \\
\cline { 3 - 4 } & & (Angka) & $(\%)$ & \\
\hline 1 & Sumber informasi & 1.290 & 4,09 & 81,90 & Tinggi \\
2 & Kemampuan mengakses & 814 & 2,58 & 51,68 & Rendah \\
& $\begin{array}{l}\text { informasi pada media } \\
\text { sosial }\end{array}$ & & & & \\
\hline & Rata- rata & 1.052 & 3,33 & 66,79 & Sedang \\
\hline
\end{tabular}


Capaian hasil penumbuhan jejaring kerjasama seperti yang ditujukan pada Tabel 5 nilai tertinggi diperoleh pada indikator yang diajak kerjasama oleh kelompok tani dengan nilai pencapaian skor 3,73 (74,79\%) dengan kategori tinggi. Selama ini yang sering diajak kerjasama dengan antar kelompok tani lainnya, gabungan kelompok tani (Gapoktan), koperasi, jarang melakukan kerjasama dengan pelaku pemasaran hasil. Sedangkan indikator yang diajak kerjasama oleh kelompok tani mendapatkan nilai 3,05 $(61,14 \%)$ yang tergolong sedang. Bentuk sistem kerjasama petani cabai-tembakau seperti melakukan percontohan (demplot), pertukaran informasi teknologi, jarang kelompok tani melakukan informasi dibidang pemasaran. Rata-rata capaian hasil penunmbuhan jejaring kerjasama memperoleh hasil nilai pencapaian skor 3,39 $(67,96 \%)$ dengan kategori sedang.

Tabel 5. Capaian Hasil Penumbuhan Jejaring Kerjasama

\begin{tabular}{llccrl}
\hline \multirow{2}{*}{ No } & \multirow{2}{*}{$\begin{array}{l}\text { Penumbuhan } \\
\text { kerjasama }\end{array}$} & \multirow{2}{*}{$\begin{array}{c}\text { Jumlah } \\
\text { skor }\end{array}$} & \multicolumn{2}{c}{$\begin{array}{c}\text { Pencapaian } \\
\text { skor }\end{array}$} & Kategori \\
\cline { 3 - 4 } & & & $($ Angka) & $(\%)$ & \\
\hline 1 & $\begin{array}{l}\text { Yang diajak Kerjasama } \\
2\end{array}$ & 1.178 & 3,73 & 74,79 & Tinggi \\
\cline { 3 - 4 } & $\begin{array}{l}\text { Bentuk sistem } \\
\text { Kerjasama }\end{array}$ & 963 & 3,05 & 61,14 & Sedang \\
\hline & Rata-rata & 1.070 & 3,39 & 67,96 & Sedang \\
\hline
\end{tabular}

Produksi cabai, tembakau dan pendapatan seperti pada Tabel .6 menunjukan, produksi buah cabai tertinggi memiliki interval kisaran produksi $>14.548 \mathrm{~s} / \mathrm{d} 16.210 \mathrm{~kg} / \mathrm{ha}$ yang diperoleh pada 15 orang responden $(04,76 \%)$ dengan kategori sangat tinggi; sedangkan $60(19,04 \%)$ responden mendapatkan produksi buah cabai $7.900 \mathrm{~s} / \mathrm{d} 9.562 \mathrm{~kg} / \mathrm{ha}$ dengan kategori sangat rendah. Secara keseluruhan rata-rata produksi cabai didapatkan 11.219 $\mathrm{kg} / \mathrm{ha}$ dengan kategori yang rendah.

Produksi tembakau kering, produksi tertinggi dicapai oleh $9(02,85 \%)$ responden, dengan kisaran produksi $>1.276-1.400 \mathrm{~kg} / \mathrm{ha}$ yang termasuk kategori sangat tinggi; sedangkan produksi terendah dicapai oleh 45 (14,28\%) responden dengan kisaran produksi $780 \mathrm{~s} / \mathrm{d} 904 \mathrm{~kg} / \mathrm{ha}$ dengan kategori sangat rendah. Secara keseluruhan rata-rata produksi tembakau kering didapatkan $1.023 \mathrm{~kg} / \mathrm{ha}$ dengan kategori yang masih rendah.

Tabel 6.

Capaian Hasil Produksi

\begin{tabular}{|c|c|c|c|c|c|}
\hline \multirow{3}{*}{ No } & \multirow{3}{*}{$\begin{array}{l}\text { Produksi dar } \\
\text { pendapatan }\end{array}$} & \multirow{3}{*}{$\begin{array}{c}\text { Interval produksi } \\
\text { (Kg/ha)/pendapatan } \\
\text { (Rp/Ha) }\end{array}$} & \multirow{3}{*}{$\begin{array}{c}\begin{array}{c}\text { Jumlah } \\
\text { responden }\end{array} \\
\text { (Orang) }\end{array}$} & \multirow{3}{*}{$\begin{array}{c}\begin{array}{c}\text { Persentase } \\
\text { responden }\end{array} \\
(\%)\end{array}$} & \multirow{3}{*}{ Kategori } \\
\hline & & & & & \\
\hline & & & & & \\
\hline \multirow[t]{6}{*}{1} & Produksi & $7.900-9.562$ & 60 & 19,04 & Sangat rendah \\
\hline & cabai & $>9.562-11.224$ & 119 & 37,77 & Rendah \\
\hline & & $>11.224-12.886$ & 69 & 21,90 & Sedang \\
\hline & & $>12.886-14.548$ & 52 & 16,50 & Tinggi \\
\hline & & $>14.548-16.210$ & 15 & 04,76 & Sangat tinggi \\
\hline & Rata-rata & 11.219 & & & Rendah \\
\hline \multirow[t]{6}{*}{2} & Produksi & $780-904$ & 45 & 14,28 & Sangat rendah \\
\hline & tembakau & $>904-1.028$ & 167 & 53,01 & Rendah \\
\hline & & $>1.028-1.152$ & 48 & 15,23 & Sedang \\
\hline & & $>1.152-1.276$ & 46 & 14,60 & Tinggi \\
\hline & & $>1.276-1.400$ & 9 & 02,85 & Sangat tinggi \\
\hline & Rata-rata & 1.023 & & & Rendah \\
\hline
\end{tabular}


Model pemasaran penguatan kelompok tani tumpangsari cabai-tembakau yang ada diprovinsi Bali selama ini memiliki potensi yang baik untuk diusahatanikan karena sudah memiliki kelembagaan kelompok tani yang baik, yang didalamnya sudah sering melakukan pertemuan untuk membahas masalah pertanian, sudah memiliki aturan tertulis, memiliki sumber informasi yang baik dan sudah sering melakukan kerjasama antar kelompok tani lainnya yang ada disekitar wilayahnya. Disamping potensi keberadaan kelompok tani tumpangsari cabai-tembakau ini juga memaliki kelemahan seperti pemasarannya masih rendah, produksi masih tergolong kategori rendah, dan kemampuan mengakses informasi sosial media juga tergolong masih kurang. Mengatasi permasalahan tersebut perlu dilakukan perbaikan pada subsistem pemasaran. Selama ini wilayah penjualan cabai dan tembakau masih didalam desa sendiri, tempat penjualan masih kebanyakan dipengepul, harga cabai kebanyakan masih ditentukan oleh pengepul, serta petani kurang peka terhadap informasi pasar. Hal ini sesuai dengan penelitian yang dilakukan oleh Adnyana, et al., (2020), bahwasannya permasalahan hasil-hasil pertanian pada komoditi cabai-tembakau terjadi pada subsistem pemasarannya.

Mengatasi permasalah tersebut, perlu dibuatkan suatu wadah sederhana berupa kelembagaan seperti koperasi atau juga bisa memanfaatkan Gabungan Kelompok Tani (Gapoktan) yang sudah ada disetiap desa setempat. Kelembagaan ini diharapkan bisa bekerja secara lebih profesional dengan mengakomodir sumber daya manusia yang handal dibidang pemasaran cabai-tembakau.

Memperhatikan perkembangan teknologi yang ada dengan mengantisipasi membludaknya cabai-tembakau pada musim panen raya, perlu dibuatkan pengolohan komoditi lanjutan (agroindustri) yang baik sesuai dengan standarnya. Pengolahan lanjutan ini diharapkan dapat meningkatkan mutu produk agar dapat memenuhi kebutuhan pasar dan selera konsumen (Suparta, 2005). Seperti cabai bisa dibuatkan bubuk olahan yang telah siap dipakai dan tembakau bisa dibuatkan bahan rokok kretek, sehingga pemarannya menjadi lebih luas dan bervariasi seperti pemasaran ke hotel/restoran, secara one line, distributor, pengepul, pasar tradisional, serta ke konsumen langsung melalui lembaga-lembaga adat yang sering melakukan upacara keagamaan. Apabila model pemasaran ini berjalan lancar diharapkan akan dapat meningkatkan pendapatan petani tumpangsari cabai-tembakau yang ada di Provinsi Bali. Model Pemasaran Penguatan Kelompok Tani Tumpangsari Cabai-Tembakau Provinsi Bali dapat dilihat pada Gambar 1. 


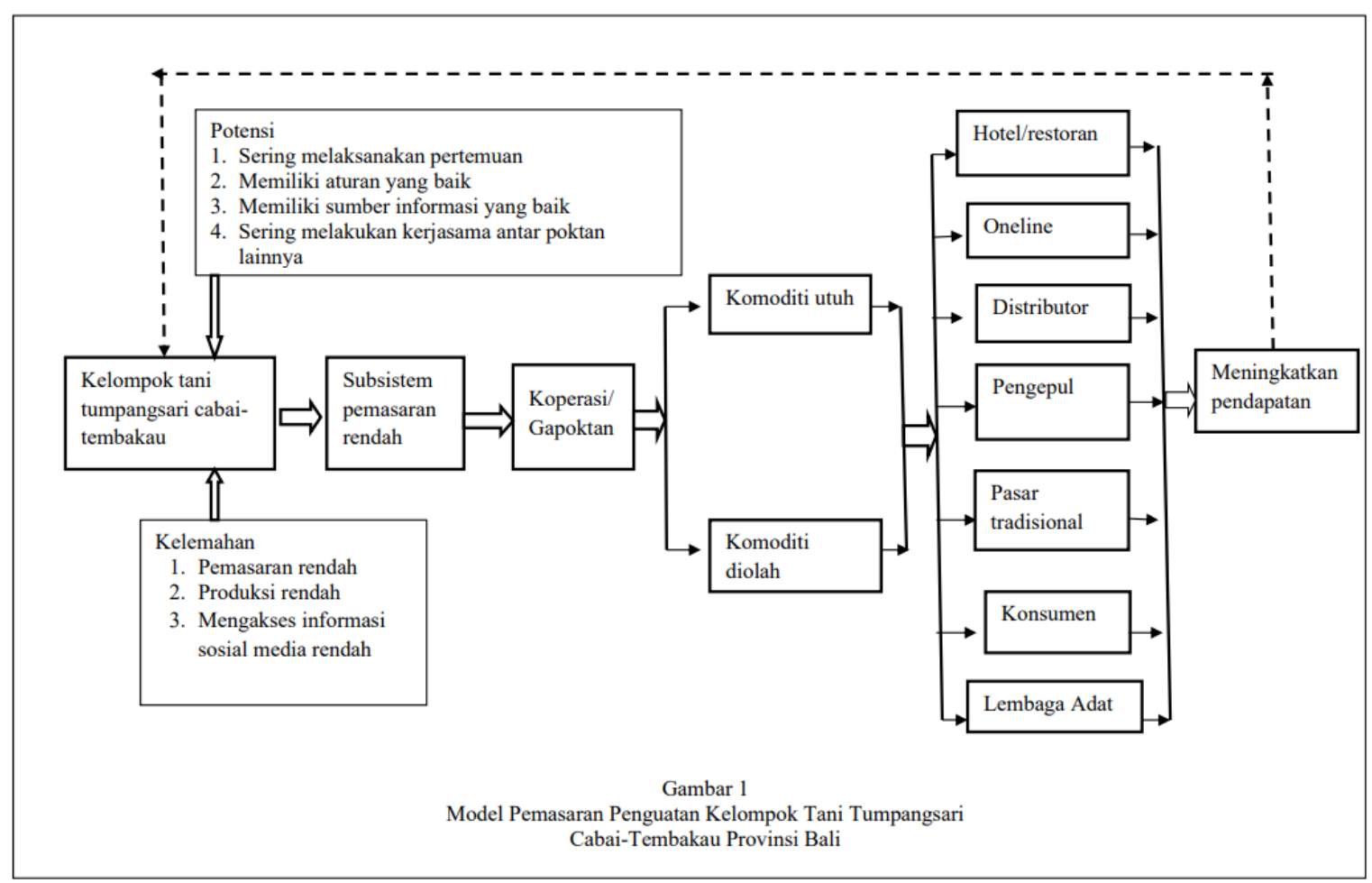

\section{SIMPULAN DAN SARAN}

\section{Simpulan}

Subsistem pemasaran hasil yang meliputi wilayah penjualan, tempat penjualan, penentuan harga, dan informasi pasar termasuk kedalam kategori rendah. Model pemasaran untuk penguatan kelompok tani cabai-tembakau dapat dilakukan dengan pembentukan koperasi/Gabungan Kelompok Tani (Gapoktan) secara profesional, dengan menjual komoditi yang masih utuh maupun komoditi cabai dan tembakau yang sudah mengalami pengolahan hasil.

\section{Saran}

Wilayah penjualan, tempat penjualan hendaknya diperluas kembali ke wilayah yang lebih luas. Penentuan harga komoditi cabai-tembakau hendaknya berdasarkan analisa usahatani yang dilakukan oleh petani. Informasi pasar bagi petani ditingkatkan kembali. Pembentukan lembaga koperasi atau Gabungan kelompok Tani (Gapoktan) yang sudah terbentuk segera dimanfaatkan untuk menangani pemasaran hasil cabai-tembakau.

\section{DAFTAR PUSTAKA}

Adnyana, N.S, Tenaya, M.N, dan Darmawan, D.P, 2017. Peranan Sistem Agribisnis Terhadap Keberhasilan Tumpangsari Cabai-Tembakau (Kasus Subak di Desa Sukawati, Kecamatan Sukawati, Kabupaten Gianyar). Journal Manajemen Agribisnis, Program Studi Magister Agribisnis, Program Pasca Sarjana, Universitas Udayana, 5(1):64-79. 
Adnyana, N.S., Darmawan, D.P., Windia, W, and Suamba, K, 2020. Agribusiness Development Model For Strengthening The Chili-Tobacco Intercroping Farmer Group. International Journal Of Life Sciences. 4(1):26-36.

Istanto, Roessali, W, Setiadi, A. (2016). Analisis Pemasaran Kubis (Brassica Oleracea L.Var. Cagitata L) di Subterminal Agribisnis (STA) Jetis Kabupaten Semarang. Jurnal Mediagro, Program Studi Megister Agribisnis Program Pasca Sarjana, Universitas Diponegoro, 12(2): 1-10.

Soekartawi. 1988. Prinsip Dasar Komonikasi Pertanian. Penerbit Universitas Indonesia. Jakarta.

Suparta, N. 2005. Pendekatan Holistik Membangun Agribisnis. Denpasar: CV Bali Media Adhikarsa. 